JANINA STANKIEWICZ

BARTOSZ SEILER

HANNA BORTNOWSKA

\title{
Motivation of \\ management students to \\ engage in volunteering \\ (in the light of research \\ results)'
}

Prof. Janina Stankiewicz

University of Zielona Góra

Faculty of Economics and Management

Bartosz Seiler, Ph.D.

University of Zielona Góra

Faculty of Economics and Management

Hanna Bortnowska, Ph.D. Eng.

University of Zielona Góra

Faculty of Economics and Management

\section{Introduction}

Non-governmental (non-profit, civic, social, voluntary, third sector) organizations are "labor-intensive" entities that operate with the support of volunteers (voluntary workers, social workers) - people who are ready to dedicate their time and effort, voluntarily and free of charge, for the fulfillment of these entities' goals ${ }^{2}$.

Volunteers form a special category of civic organization workers. They represent a peculiar mix of behaviors, traits and motivations, contributing to the specific, community-like atmosphere of non-profit organizations. Without their involvement, the activities of many non-governmental actors would be hindered . It should be noted, however, that their work also comes with significant barriers. Third sector managers point to the limited availability of volunteers, their increased fluctuations and issues with

1 Carried out with the financial support of the City of Zielona Gora.

2 The results of the literature analysis included in the article and own research concern formal volunteers (working within the framework of non-profit entities), who are also internal volunteers (having the status of a member of the organization) or external volunteers (not having that status). 
the enforcement of office relations (Stankiewicz, Seiler 2011). This affects largely the organization and the structuring of the work of the actors in question. Acquiring and keeping internally motivated volunteers ${ }^{3}$, who additionally identify themselves with the objectives of the organization, seems to be one of the important factors of success in the sphere of non-profit (cf. Kafel 2014, pp. 9599). In this context, it becomes particularly important to engage volunteers with specialized skills. It is all the more essential in the face of the growing pressure on raising the standards of activity in third sector and its professionalization.

The market of volunteers in Poland, especially those with specialized skills, is limited ${ }^{4}$. Consequently, managers of civic organizations should seek possibilities of cooperation with entities of the external environment, and especially their employees who possess the required expertise. An important source of volunteer work can be provided by colleges and universities, with which the organizations in question should consider permanent cooperation. Studies show that university students manifest an above-average engagement in volunteering ${ }^{5}$. Additionally, students can be the source of relatively specialized workers, with expertise related not only to the area of activity of non-profit organizations (nursing, teaching, etc.), but also the sphere of organization (planning and realization of charity, fundraising, office support, establishing and maintaining relationships with stakeholders, etc.). According to the authors, non-profit entities may seek volunteers predisposed to provide administrative support among management students. Especially so since many Polish non-profit organizations demonstrate deficiencies in management professionalization.

This article aims to answer the following questions: Do managements students want to get involved in the activities of non-governmental organizations? What are the prevailing reasons for engaging in volunteering among them? What benefits do they see in working with non-profit entities? What measures to motivate volunteers can the managers of these organizations take? To answer these questions, empirical research was conducted.

3 Nearly one in three (31\%) non-profit organizations has difficulties in keeping competent staff and volunteers (Przewłocka, Adamiak, Herbst 2013).

4 The research carried out in 2011 by TNS Opinion \& Social at the request of the European Parliament suggests that involvement in voluntary work, compared with other European countries, is relatively small in Poland. For example, the percentage of people working in nonprofit organizations as volunteers in the Netherlands was 57\%, in Denmark - 43\%, in Finland - 39\%, Austria - 37\%, while in Poland - 9\% (Eurobarometer 2011).

5 According to data from the Polish Central Statistical Office (GUS; Główny Urząd Statystyczny, 2012), the largest group of volunteers were people aged 15-17 years (18.9\%), 18-24 (11.8\%) and 25-34 $(8.9 \%)$. 


\section{Motivation to engage in voluntary work}

Motivation is the basis of human activities. It arises when an individual feels the need, and is able to fulfill it, through a specific activity, and also when there are favorable conditions for the success of the actions taken by him or her (the attribute-based approach; Sekuła 2008, p. 9). It also stands for "the process of conscious and purposeful influence on the behavior of other people by producing in them that willingness to act" (Czerska 2002, pp. 295-296), the essence of which is the use of individually various tools and instruments of human influence (Kopertyńska 2009) (the functional approach). Understood as such, it accompanies the processes of exchange between the employee and the employer. It then consists in shaping the attitudes of the desired members of the organization in order to carry out specific tasks through conscious and deliberate influence on their behavior (Romanowska 2004).

In return, they receive a salary and other benefits gratifying their contribution to the company and encouraging further engagement in solving its problems (cf.. Sikorski 2004). In doing so, it is important to have the knowledge of the needs of individual employees and assume an individualized approach to meet them (Kopertyńska 2009). There are many forms of motivation. In addition to material forms, non-material ones can be used as well, e.g. to ensure that members of the organization participate in training, offer them promotion (vertical or horizontal), flexible working hours, increase their responsibilities, engage them in the process of company management, etc.

It should be emphasized that when analyzing the problem of motivating employees, the specifics of the internal environment of the organization should be considered. A peculiar category in this regard is third sector organizations, made up mostly of volunteers (social entrepreneurs, members, voluntary workers). Workers involved in the activities of the volunteering activity represent pro-social behavior, considered an indicator of group consciousness and a sense of unity (Załuska 1998). In examining the involvement of people in third sector, especially volunteers, one tends to indicate the situational context, but also factors related to social skills, attitudes and personality. It has been shown, among others, that volunteers are more confident, reflective and less materialistic than the rest of the population, as well as often more consistent and extrovert than paid employees (Chimiak 2006, pp. 110-124). Analyses of K. Olkowska (2008) also proved that social workers demonstrated stronger orientation of controlling their own fate and causative optimism than nonvolunteers. 
The organizations in questions have specific values and standards for activities in the community. These entities are considered to have a more democratic and stronger collectivist orientation as compared to commercial enterprises (Iwankiewicz-Rak 1997). It is emphasized that managers of these organizations must carefully weigh the balance between controlling and representing their personnel. In the case of non-profit organizations, there is, thus, a characteristic internal social environment. This special nature stems, among others, from (Bogacz-Wojtanowska 2009, p. 82):

- a sense of mission among the people involved in the organization activities,

- favoring informal organizational structures,

- an organizational culture based on values and standards conducive to friendly relations, participation and compromise.

Due to the limited resources, the possibility of financial motivation of employees in non-governmental organizations is also very limited, but it is worth considering the use of other resource - non-material, related to working conditions, atmosphere, assigning tasks. In the case of volunteers, material motivation may even be counterproductive, as indicated by the concept of the "above-standard commitment to work" (Mirońska 2016, p. 91). In her assumption, employees motivated internally compensate lower material benefits with the usefulness arising from the fulfillment of a social mission. Financial rewards offered to social workers may therefore contribute to the internal motivation being "pushed out".

Table 1. Example of higher-needs measures to motivate volunteers

\begin{tabular}{|c|c|c|}
\hline \multicolumn{3}{|c|}{ Higher-needs measures to motivate volunteers } \\
\hline Affiliation & Recognition & Development \\
\hline $\begin{array}{l}\text { - provide a pleasant } \\
\text { work environment, } \\
\text { personnel } \\
\text { friendliness, a sense } \\
\text { of community, } \\
\text { - celebrate Volunteer's } \\
\text { Day, } \\
\text { - invite to formal } \\
\text { and informal team } \\
\text { meetings, }\end{array}$ & $\begin{array}{l}\text { - give occasional gifts and } \\
\text { awards, } \\
\text { - give gadgets with the logo of } \\
\text { the organization, } \\
\text { - celebrate Volunteer's Day, } \\
\text { - send greeting cards } \\
\text { - praise and recognition, } \\
\text { - show thankfulness, } \\
\text { - include in the decision- } \\
\text { making process (if possible) }\end{array}$ & $\begin{array}{l}\text { - have advisory and } \\
\text { supportive conversations, } \\
\text { - assign tasks satisfactory } \\
\text { to the volunteer, where he } \\
\text { or she will be able to use } \\
\text { their skills and help their } \\
\text { development; explain } \\
\text { responsibilities, } \\
\text { - include in the decision- } \\
\text { making process (if possible) }\end{array}$ \\
\hline
\end{tabular}




\begin{tabular}{l|l|l} 
- show interest in the & $\bullet$ entrust responsible tasks, \\
$\bullet$ & placing the name of \\
a volunteer in the annual & $\begin{array}{l}\text { report of the organization } \\
\text { and/or the publication that } \\
\text { he or she helped with } \\
\text { inform the volunteer about } \\
\text { the results of his or her work } \\
\text { and the performance of the } \\
\text { entire organization, } \\
\text { encourage sharing } \\
\text { thoughts and ideas about } \\
\text { the functioning of the } \\
\text { organization, } \\
\text { provide tools and resources of } \\
\text { the organization } \\
\text { ensure flexible working time } \\
\text { and workplace }\end{array}$ & $\begin{array}{l}\text { informal team meetings, } \\
\text { about the results of his } \\
\text { or her work and the } \\
\text { performance of the entire } \\
\text { organization, } \\
\text { encourage sharing } \\
\text { thoughts and ideas about } \\
\text { the functioning of the } \\
\text { organization, } \\
\text { provide tools and } \\
\text { resources of the } \\
\text { organization } \\
\text { ensure flexible working } \\
\text { time and workplace }\end{array}$ \\
\hline
\end{tabular}

Source: own study based on: Basińska; Nowak 2010; Bogacz-Wojtanowska 2009; Centrum Wolontariatu 2014; Ochman, Jordan 1996; Rustecki 2011

Commitment of volunteers results, as indicated in the literature, among others from three types of motivation: self-centered, empathetic, normative (Basinska, Nowak 2010, p. 12). In the case of the first - an individual benefits from activities or in this manner creates for themselves an auspicious arrangement of external circumstances; the second - an individual helps others because they cannot stand human suffering; and the third - an individual strives to manifest behavior that is in line with moral standards. Involvement of volunteers in working for third sector organizations can be a manifestation of altruism and the desire to obtain certain benefits, e.g.: develop competence and experience, gain social recognition, establish new interpersonal relations, improve professional image, etc. (cf. Bogacz-Wojtanowska 2009).

Managers of non-profit organizations can also take measures conducive to the maintenance of satisfaction of volunteers with the volunteer work they perform. Proposals for such activities are found in the literature (cf.: Basińska, Nowak 2010; Bogacz-Wojtanowska 2009; Centrum Wolontariatu 2014; Ochman, Jordan 1996; Rustecki 2011). They refer mainly to the satisfaction of the so-called higher needs, namely affiliation, recognition and development (table 1). 
Let us note that some of the measures in table 1 can simultaneously contribute to meet the needs of several types. It is also worth noting that measures such as: involvement in the decision-making process, entrusting responsible tasks, inviting to meetings with the management, encouraging sharing of ideas on the operation of a non-profit entity, all support the growth of social satisfaction related to social work. After all, a volunteer - through the activity he or she manifests - experiences a sense of perpetration and influence on the fulfillment of the organization's objectives.

An interesting issue is to know the motives prompting management students to engage in volunteering activities. Such knowledge could be used to devise measures to motivate this type of workers. The foundation for further considerations are the results of own studies.

\section{Research methodology and characteristics of the research sample}

The research was conducted in December 2015. The technique opted for was direct survey based on a categorized and standardized questionnaire containing, inter alia, nine questions: closed and semi-open (single and multiple choice). The following scales were used: ordinal scale and Likert scale. The questionnaire also included socio-demographic variables characterizing the respondents.

The study examine the opinions of 281 deliberately ${ }^{6}$ selected full-time (56\%) and part-time (44\%) students of three courses offered within the Faculty of Economics and Management at the University of Zielona Gora: Logistics (42.7\%), Economics $(31.7 \%)$, Management $(25.6 \%)$. Among the respondents, there were more women $(68.9 \%)$ than men. The majority of the respondents $(87.9 \%)$ were 4 undergraduate students. More than half $(60.1 \%)$ were less than 22 years old. Between 2011 and 2015 , one in four $(26.3 \%)$ was involved in the activities of non-governmental organizations.

\section{Reasons for the engagement of management students in volunteering}

It is important for non-profit entities to know the reasons, or motives, for the engagement of management students in voluntary work. It was found that among those reasons dominant was the desire to help others, both in an

6 Due to protection of personal data, it was not possible to determine the size of the general population (i.e. how many surveyed students were below 26), hence the decision to select the sample deliberately, not randomly. 
autotelic (should help others - 47.3\%) and instrumental (if I help others, others will help me in the future - 35.3\%, I will return the help given - $13.5 \%$ ) way. The respondents rarely expressed the readiness get involved in volunteering because of career development and improvement - acquiring new knowledge and skills (42.5\%) and/or CV enrichment and improving professional image (30.4\%). For every third student (33\%) the potential cause of the engagement in the voluntary activity would be the opportunity to meet new people, satisfying the need for affiliation and allowing to build social capital. Some respondents (22.7\%), through involvement in voluntary work, would like to manage their free time in a productive way.

By going deeper into the analysis, the benefits that - according to the respondents - volunteering may bring were also determined. More than half considered that voluntary work creates the opportunity to improve social skills (63.3\%), technical skills (60.9\%). For many (61.4\%) it was also the possibility of meeting someone who would help them find a job in the future. Slightly fewer respondents (57\%) said that volunteering also facilitates $\mathrm{CV}$ enrichment and thus building a positive professional image. For every third respondent (35.8\%), this kind of activity promotes development of professional interests, while every fifth $(22.2 \%)$ saw in it an opportunity to make money ${ }^{7}$. Very few respondents $(4.8 \%)$ thought volunteering was a waste of time.

To sum up, the reasons for engagement in volunteering were mostly altruistic, resulting from the need to help others, but at the same time it was also important for the respondents to strive for meeting their needs, including those related to development and belonging. The respondents also perceived benefits of working in non-governmental organizations, especially the positive impact on their careers. The presented research results can provide guidance to non-profit organizations in developing recruitment campaigns and motivation systems targeting this segment of volunteers.

7 Weak correlations between the statements of the respondents and their socio-demographic characteristics was identified. The values of coefficients Fi (Yule's) and V-Cramer did not exceed 0.3. The article includes the following scale for the V-Cramer coefficient: $|\mathrm{r}|=0$ (correlation does not exist), $0<|\mathrm{r}|<0.3$ (poor), $0,3 \leq|\mathrm{r}|<0.5$ (average), $0,5 \leq|\mathrm{r}|<0.7$ (significant) $0,7 \leq|\mathrm{r}|<0.9$ (high) $0,9 \leq|\mathrm{r}|<1.0$ (very high), $|\mathrm{r}|=1$ (full) (Stanisz 2006). In addition, following Cohen, it was assumed that fi of 0.1 or less is a small effect; $(0.1 ; 0.3>$ is average, and greater than or equal to 0.5 large (Arcimowicz et al.., www.staff.amu.edu.pl/ uamzpoip/corobia.../Effect\%20size.ppt, 02.07.15 - date of access). 


\section{Measures taken in non-profit organizations to motivate volunteers - management students}

Taking into account the reasons why the student respondents engage in volunteering, analyzed were the measures taken in non-governmental organizations with the aim to motivate social work. Let us recall that the study participants were (would be) most often willing to work for non-profit entities, because they wanted (would like) to help people in need. It also was (would be) important for them to meet their own needs, namely development and affiliation. So, does working with third sector organizations offer the opportunity to fulfill those needs?

It seems that non-governmental organizations have been able to create for volunteers an environment conducive to the development of competence. More than half of the study participants (52.7\%) continued fulfilling responsible tasks (39.2\%), and less frequently those that demanded independence. One in four $(25.7 \%)$ performed the work with a high degree of differentiation, thus eliminating mundanity. The same percentage of volunteers participated in projects. Every ninth respondent (13.5\%) participated in training, and one in ten $(10.8 \%)$ - in regular meetings, during which experiences and opinions were exchanged with other members of non-profit organizations. The research shows that the activity within these entities offered a greater opportunity for development through performing important tasks, but smaller in terms of improving skills in the course of internal and external training.

The research results are the basis for arguing that the non-governmental organizations have been able to provide the conditions for students to fulfill their needs of affiliation. Almost half (44.6\%) of the respondents experienced a nice working environment, every third $(36.5 \%)$ felt the interest in his or her activity, and every fifth (17.6\%) - took part in social events.

The research also showed that non-profit organizations take measures to ensure that the respondents meet their need for recognition. To do this, they: offered praise and recognition (in writing, in the form of diplomas - $48.7 \%$, verbally $-20.3 \%$, in newsletters or on the website $-9.5 \%$ ), reported on the impact of a volunteers on the functioning of the non-profit entity (14.9\%), placed his or her name in the annual report or in the publication that he or she helped prepare $(12.2 \%)$. Included also were the ideas of the respondents concerning the activities of the organization of which they were participants (10.8\%).

It is worth mentioning that material incentives were also used, e.g..: prizes, gifts $(21.6 \%)$, gadgets with the logo of the organization (13.5\%), free entries/ 
tickets to the gym, cinema, theater $(6.8 \%)$, financial rewards $(5.4 \%)$. Few $(1.4 \%)$ were offered a chance to participate in projects that allowed them to make extra money. This can be explained by the limited possibilities in this respect. At the same time, let us note that only every tenth participant of the research found themselves not motivated for work.

Vast majority of the respondents (93.2\%) positively rated their experience of working in third sector organizations. Most often they defined them as good $(43.2 \%)$ or very good $(37.8 \%)$. On the other hand, one in nine $(12.2 \%)$ found them to be merely sufficient, and very few (4.1\%) - inadequate. All the respondents would recommend others to work in a non-governmental organization (definitely - 55.4\%, rather - 44.6\%). None of the participants of the research considered working with a non-profit organization to be a waste of time. It was an opportunity, first of all, to help others (70.3\%), but also allowed the fulfillment of higher needs. According to more than half of the respondents, thanks to the involvement in voluntary activities, one can establish and maintain relationships with interesting people (52.7\%) and / or improve one's skills (51.4\%). Many also noticed the chance of acquiring valuable work experience (43.2\%) and develop interests (39.2\%).

The research results showed that non-profit organizations took various measures to motivate volunteers. Most of the surveyed students experienced it (on average, in five different forms), although their widespread application was limited (entrusting responsible tasks was applied to only half of the respondents; other measures were taken less frequently). The skills of managers of third sector managers regarding motivating volunteers should be improved.

The research also showed that the majority of the respondents $(93 \%)$ positively assessed the cooperation with non-governmental organizations, which could be the result of not only management interaction, but also of internal motivation for volunteering and successfully maintaining this motivation in the course of work .

\section{Conclusion}

Non-governmental organizations operate with the support of social workers. As indicated by the research results, attracting and keeping competent and committed voluntary staff poses a significant challenge to Polish non-profit entities'. In this context, volunteering should be presented to young people as an opportunity to develop the skills they need in today's labor market.

An important source of volunteers are students are college and university students. An important target group for non-profit entities may be those who 
study towards a degree in management which prepares them for executive roles. For such students, i.e. management students, working with third sector organizations provides an opportunity to develop the knowledge and skills associated with management, as well as expand interpersonal skills. It is therefore crucial to explore the reasons for undertaking voluntary and unpaid engagement in work and the opinions on the experience of working with nongovernmental organizations. Such knowledge proves useful in the development of systems aimed at motivating volunteers.

The research results show that the main for the respondents to engage in voluntary activity is the desire to help others. Cooperation with non-profit organizations also indicated a chance of fulfilling higher needs, such as: getting to know new people, improve skills, career development. Vast majority of the respondents positively assessed their cooperation with non-governmental organizations. Significant in this respect was internal motivation and, to some extent, measures taken by the management that were conducive in terms of fulfilling some needs of the volunteers. It is necessary to develop the skills of managers of non-profit organizations regarding motivating social workers. Although it was established that they implemented a rather wide spectrum of measures sustaining commitment, these still should require to be expanded. After all, not all of them are associated with incurring significant financial expenditures. Some require the knowledge of intangible ways to motivate volunteers and of potential consequences of their application in practice.

\section{Summary}

\section{Motivation of management students to engage in volunteering (in the light of research results)}

Market of volunteers in Poland, especially those ones with specialized skills, is limited. An important reservoir of volunteer work are the universities. Non-governmental organizations should consider sustained cooperation with them. Volunteers predisposed to provide administrative support could be sought among the students of management. This article aims to answer the following questions: Are students of management want to get involved in the activities of non-governmental organizations? What are the motives of involvement in voluntary dominate among them? What benefits do they see, in collaboration with NGO's? What actions can take the managers of these organizations to motivate volunteers? 
Keywords: non profit organizations, volunteers, motivation, management students.

\section{Streszczenie}

Motywacja studentów kierunków menedżerskich do angażowania się $w$ wolontariat ( $w$ świetle wyników badań) Rynek wolontariuszy w Polsce, szczególnie tycho specjalistycznych umiejętnościach, jest ograniczony. Ważny rezerwuar pracy ochotniczej stanowią wyższe uczelnie, z którymi organizacje pozarządowe powinny rozważyć stałą współpracę. Wolontariuszy predysponowanych do udzielania wsparcia administracyjnego można poszukiwać wśród studentów kierunków menedżerskich. Celem artykułu jest udzielenie odpowiedzi na pytania: Czy studenci kierunków menedżerskich chcą zaangażować się w działalność organizacji pozarządowych? Jakie motywy zaangażowania $\mathrm{w}$ wolontariat dominują wśród nich? Jakie korzyści dostrzegają we współpracy z pomiotami non profit? Jakie działania służące zmotywowaniu wolontariuszy mogą podjąć menedżerowie takich organizacji?

\section{Słowa}

kluczowe: organizacje non profit, wolontariusze, motywacja, studenci kierunków menedżerskich.

\section{References}

1. Arcimowicz B., Kubiak A., Stańko M., Haładziński P., Kaczmarek L., Wielkość efektu, www.staff.amu.edu.pl/ uamzpoip/co_robia... / Effect\%20size.ppt (02.07.2015 - access date).

2. Basińska A., Nowak M. (2010), Motywowanie $i$ motywacja do pracy wolontariuszy, WOLIMP, Poznań, http://www.staff.amu.edu.pl/ wolimp (24.08.2016 - access date).

3. Bogacz-Wojtanowska E. (2009), Zarządzanie kadrami w organizacjach pozarzadowych, [in:] E. Bogacz-Wojtanowska, M. Rymsza (eds.), Nie tylko społecznie. Zatrudnienie i wolontariat w organizacjach pozarzadowych, Instytut Spraw Publicznych, Warszawa.

4. Centrum Wolontariatu (2014), Motywowanie, http://wolontariat.org.pl/ strefa-korzystajacych/ cyklwspolpracy/wspolpraca-i-motywowanie/ motywowanie/ (20.05.2014 - access date).

5. Chimiak G. (2006), How indyvidualists make solidarity work, MPiPS, Warszawa.

6. Czerska M. (2002), Motywacja, in: A. Czermiński, M. Czerska, B. Nogalski, R. Rutka, J. Apanowicz, Zarzadzanie organizacjami, TNOiK „Dom Organizatora", Torun. 
7. Eurobarometer (2011), Volunteering and Intergenerational Solidarity. Report, Brussel, http://www.europarl.europa.eu/pdf/eurobarometre/2011/ juillet/04_07/rapport_\%20eb75_2_\%20benevolat_en.pdf $\quad$ (29.09.2016 access date).

8. Główny Urząd Statystyczny (2012), Wolontariat w organizacjach i inne formy pracy niezarobkowej poza gospodarstwem domowym - 2011, Warszawa.

9. Iwankiewicz-Rak B. (1997), Marketing organizacji niedochodowych. Wybrane problemy adaptacji w warunkach polskich, Monografie i Opracowania No. 121, Wydawnictwo Akademii Ekonomicznej, Wrocław.

10. Kafel T. (2014), Metody profesjonalizacji organizacji pozarzadowych, Wydawnictwo Uniwersytetu Ekonomicznego w Krakowie, Kraków.

11. Kopertyńska M.W. (2009), Motywowanie pracowników. Teoria i praktyka, Placet, Warszawa.

12. Mirońska D. (2016), Relacje $z$ interesariuszami organizacji non profit $z$ perspektywy marketingowej, Oficyna Wydawnicza Szkoły Głównej Handlowej, Warszawa.

13. Ochman M, Jordan P. (1996), Jak pracować z wolontariuszami, Warszawa, www.procarpathia.pl/download/.../jak_pracowac_z_wolontariuszami. pdf (24.08.2016 - access date).

14. Olkowska K. (2008). Optymizm sprawczy i orientacje kontroli wśród wolontariuszy, [in:] D. Rutkowska, A. Szuster (eds.), O różnych obliczach altruizmu, Wydawnictwo NaukoweScholar, Warszawa

15. Przewłocka J., Adamiak P., Herbst J. (2013), Podstawowe fakty o organizacjach pozarządowych w Polsce. Raport z badania 2012, Stowarzyszenie Klon/Jawor, Warszawa.

16. Romanowska M. (ed.) (2004), Leksykon zarzadzania, Difin, Warszawa.

17. Rustecki W. (ed.) (2011), Praktyczny poradnik wspótpracy z wolontariuszami, Fundacja Pracownia Badań i Innowacji Społecznych Stocznia, Warszawa.

18. Sekuła Z. (2008), Motywowanie do pracy. Teorie $i$ instrumenty, PWE, Warszawa.

19. Sikorski Cz. (2004), Motywacja jako wymiana - modele relacji między pracownikiem a organizacja, Difin, Warszawa.

20. Stanisz A. (2006), Przystęny kurs statystyki z zastosowaniem STATISTICA PL na przykładach z medycyny, Vol. 1, StatSoft Polska, Kraków

21. Stankiewicz J., Seiler B. (2011), Możliwości $i$ bariery zatrudniania płatnych pracowników w organizacjach non profit jako ważny czynnik ich sukcesu, Prace i Materiały Wydziału Zarządzania Uniwersytetu Gdańskiego, No. 4/1.

22. Załuska M. (1998), Społeczne uwarunkowania angażowania się w działalność organizacji pozarząowych, [in:] M. Załuska, J. Boczoń (eds.), Organizacje pozarządowe w społeczeństwie obywatelskim, BPS, Katowice. 